\title{
The Morphological Observations of Some Lingual Papillae in the Prenatal and Prepuberal Stages of Red Sokoto Goats (Capra hircus)
}

\author{
Observaciones Morfológicas de Algunas Papilas Linguales en las Etapas Prenatal y Prepuberal de \\ Cabras Rojas de Sokoto (Capra hircus)
}

Igbokwe, C. O. \& Okolie, C.

IGBOKWE, C. O.\& OKOLIE, C. The morphological observations of some lingual papillae in the prenatal and prepuberal stages of red sokoto goats (Capra hircus). Int. J. Morphol., 27(1):145-150, 2009.

SUMMARY: This study was carried out to investigate the morphological development of the tongue in the foetal and prepubertal stages of Red Sokoto goats by light microscopy. In foetuses of about 50 days, the tongue tissues showed thickening of the epithelium into about 2-3 layers of cells. In fetuses of about 65 days, mesenchymal tissue was observed under the epithelium.Rudiments of some papillae were observed at this time. Collagenous fibre and blood vessels were scant in the lamina propria. In the 80-day-old foetuses, their was further differentiation of the epithelium rudiments into some papillae and this continued to mature until in foetuses of about 90 and 110 days, were early rudiments of taste buds were observed. Evidence of keratinization was apparent in the prepubertal stages.

KEY WORDS: Development; Lingual papilla; Red Sokoto goats.

\section{INTRODUCTION}

The surface anatomy and histology of the adult tongue of domestic animals and its papillae is described in numerous textbooks of Histology (Bloom \& Fawcett, 1994; Ham \& Cormack, 1979; Dellman, 2006). Numerous research studies investigated morphogenesis of lingual papillae in various animal species (Ahpin et al., 1989; Tichy, 1992; Fujimoto et al., 1993; Iwasaki et al., 1996a; Kulawik, 2005a, 2005b) and human (Witt \& Reutter, 1997). The available reports were entirely concerned with adult structures of the tongue and papillae, much less has been written about the prenatal development of the lingual papillae in the goat.

This work described the light microscopic features of the development of the lingual papillae at the foetal and prepubertal stages in the Red Sokoto goat (Capra hircus), an important breed of goat in Northern Nigeria. The report will also add to the existing information on the morphogenesis of the tongue in goats.

\section{MATERIAL AND METHOD}

Tongues used for this study were obtained from 30 foetuses, 5 prepubertal goats of Red Sokoto goats. The specimens were obtained an abbattor in Nsukka town (foetuses). While the younger prepubertal animals were purchased, and slaughtered humanely. Ages of the foetuses were estimated using crown-to-rump lenght using the formula: (days (age of foetus $)=($ CRL+17) 2.1 according to Richardson et al. (1976) and other goats were used by dentition (Soan et al., 1997).

The tongue tissues were fixed in Bouin's fluid, dehydrated in graded series of ethanol, cleared in xylene and embedded in paraffin wax. The blocks of tissues of tongue from apex, middle and root of the tongue were sectioned in transverse and longitudinal planes of the dorsum of the tongue. The slides were stained with hematoxylin and eosin. Selected sections were photographed with Leica (Gallen III) photomicroscope with Moticam MC 2001 digital camera attachement and the observations captured on a Laptop Computer. The morphological features were noted. 


\section{RESULTS}

In the foetuses of about 50-day-old, the sections taken from the dorsum of the apex and the body of tongue was covered by 2-3 layers of epithelial cells. The cells at the basal layer have large oval or round nuclei, while the apical cells consisted of lower cells, their nuclei being flattened. Mitotic figures were found in the epithelium. A well defined basement membrane was apparent. Underlying it is the mesenchymal tissue with cells having oval nuclei and some amount of cytoplasm (Fig. 1). Some of the tongues of the fetuses of about 50-day old showed epithelial thickenings on the dorsum and in the apex of the tongue, the highest concentration being at the apex of the tongue. These thickenings probably were early rudiments of some lingual papillae.

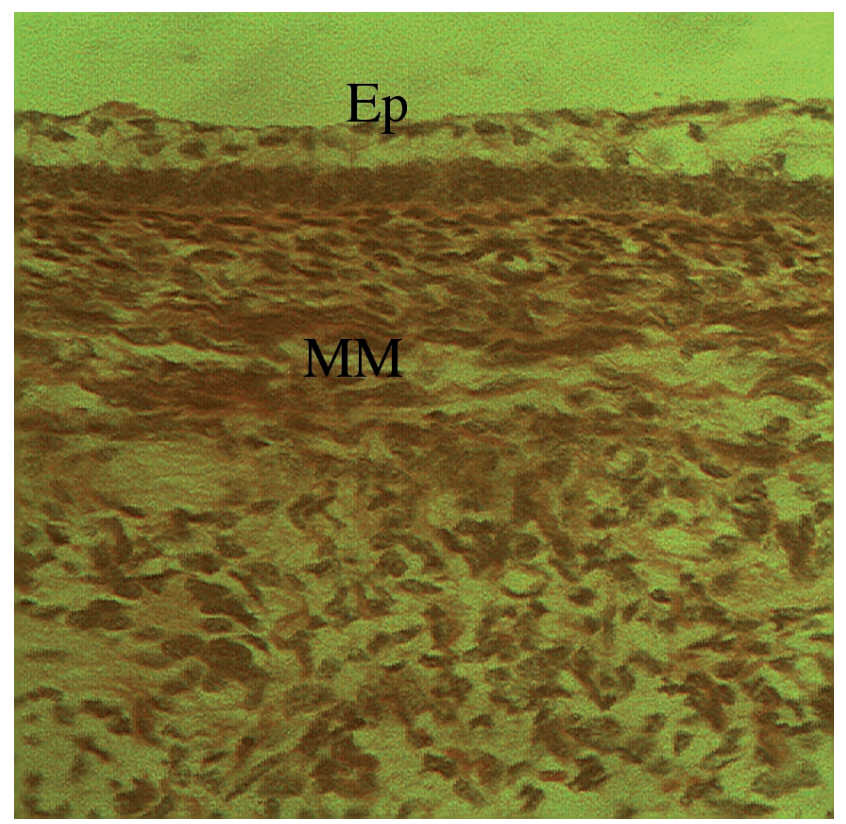

Fig. 1. 50-day; epithelial thickening (Ep); mesenchyme (MM); connective tissue core. H \& E. X200.

In the foetuses of about 65-day-old, there was further maturation of the epithelium.The dorsum of the apex, the body and root of the tongue showed rudiments of filiform and fungiform papillae which was quite apparent. The arrangement of the rudiments of filiform papillae is similar to the distribution of epithelial thickenings. (Fig. 2). The epithelial thickenings showed that cells are in about 3-4 layers, with the basement membrane very apparent which rested on well defined lamina propria. No mitotic figures where observed in the epithelial covering. The lamina propria of the mucous membrane formed protrusions, constituting the connective tissue core of the developing lingual papillae.

In the foetuses of about 80-day -old, there was further

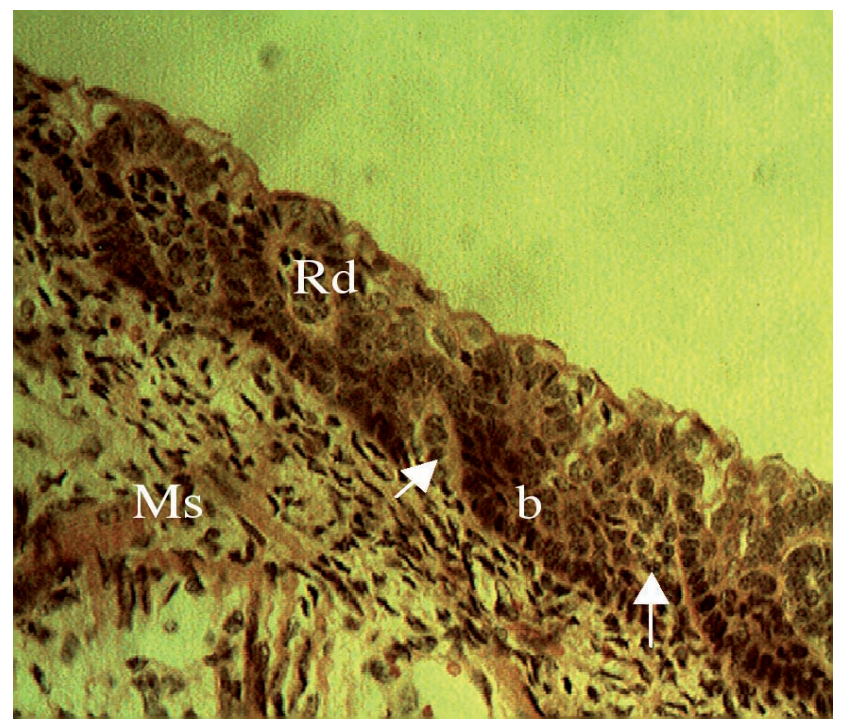

Fig. 2. 65-day; rudiments of papillae (Rd), basal (basal cells), muscle cells (Ms). X200, H \& E.

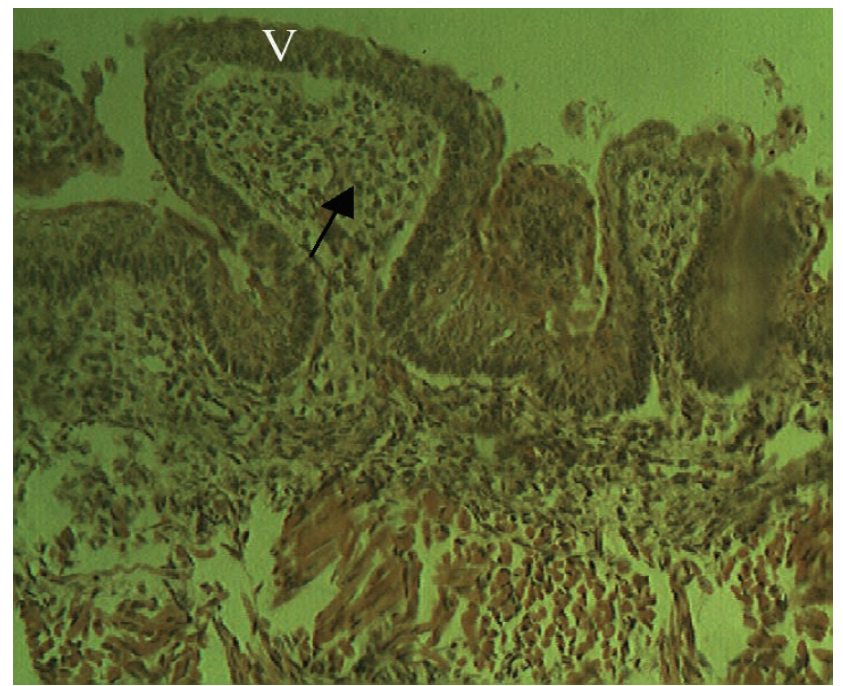

Fig. 3. 80-day; Vallate papillae (V), connective tissue core (arrow), muscle fibres (m). H \& E. X200.

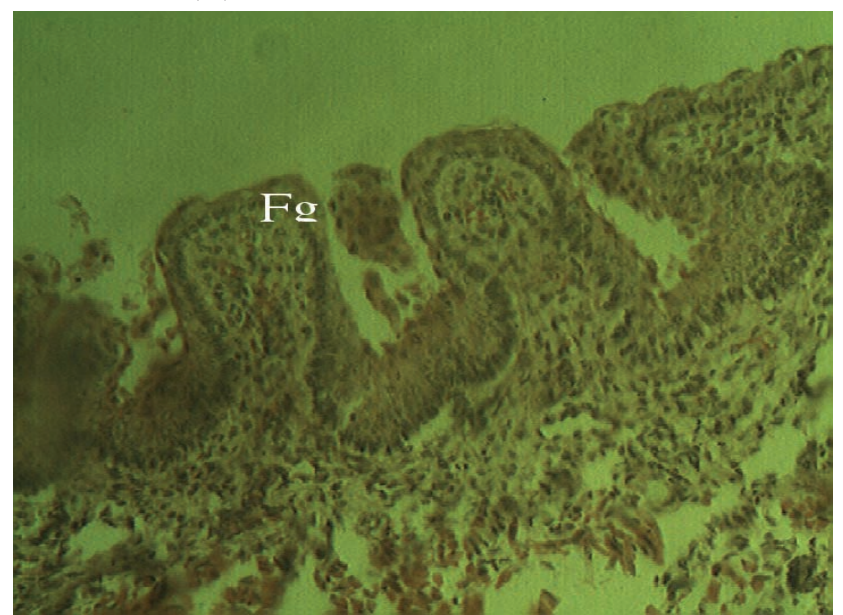

Fig. 4. 80-day; developing fungiform papillae. H \& E. X200. 
maturation of the papillae; primordial of filiform, vallate, fungiform were very apparent. There were marked differences from the previous age group. Collagenous fibres and blood vessels were present in the lamina propria (Figs. 3 and 4). The vallate papillae showed maturation and folding of the epithelium.

In the 90-day-old foetuses, the lingual papilla looked continued to mature with some rudiments of taste buds apparent on the fungiform papillae.The presence and maturation of the filiform papillae was also apparent but no evidence of keratinization was seen (Figs. 5 and 6). Muscle fibres and connective tissues look well developed.

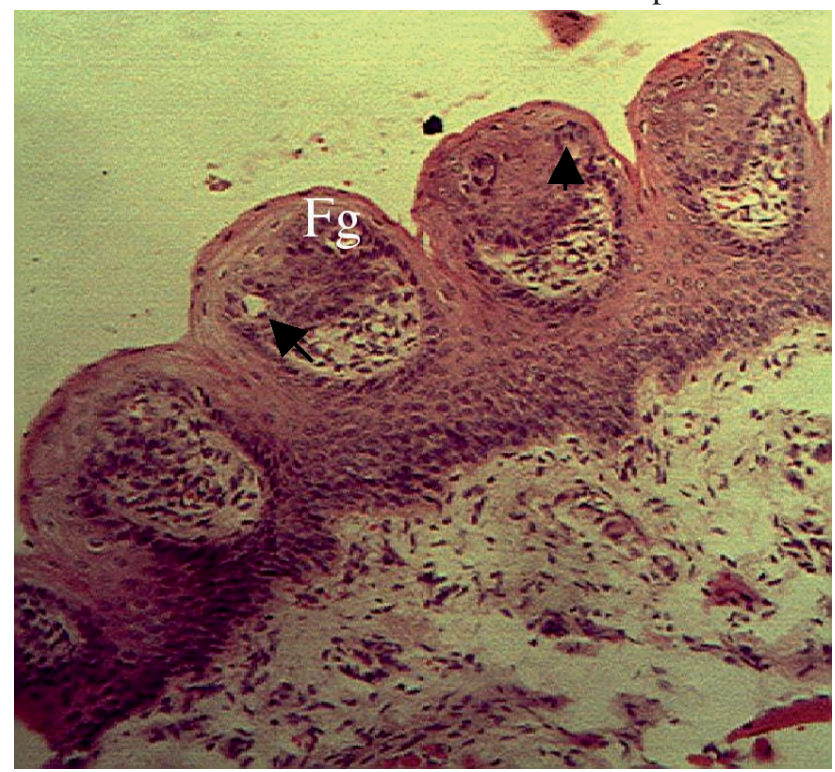

Fig. 5. 90-day; fungiform papillae, muscle fibres(M). Rudiments of taste buds(arrows). H \& E. X200.



Fig. 6. 90-day; filiform papillae,muscle fibres(M).H \& E. X200.

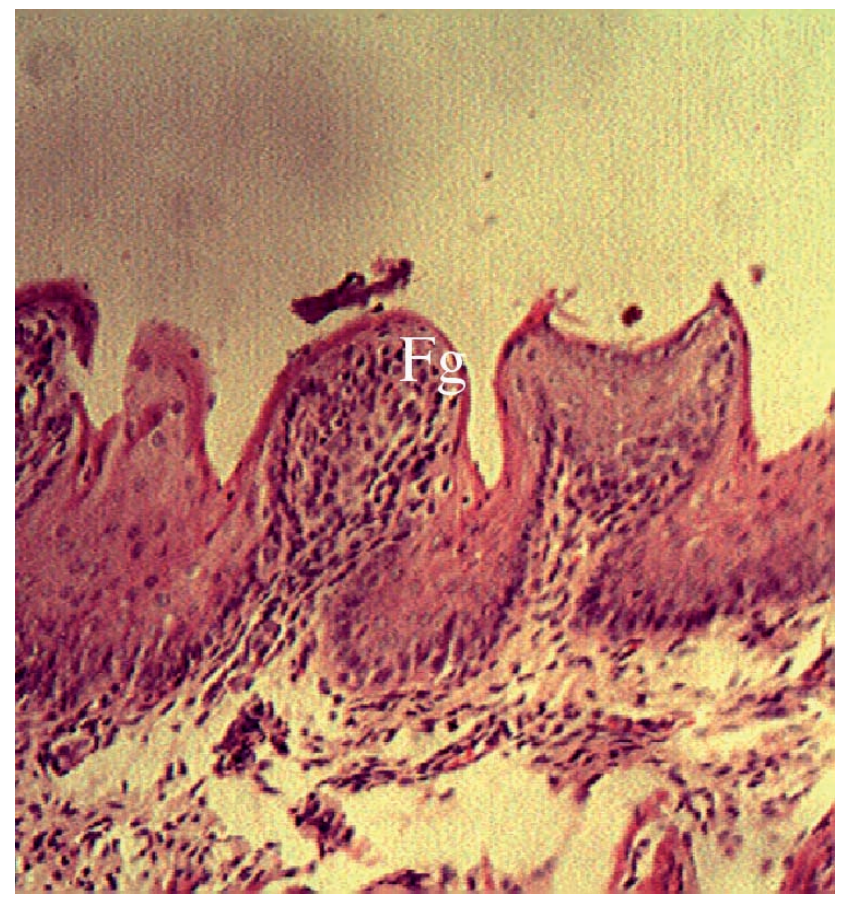

Fig. 7. 110-day; fungiform papillae. H \& E. X200.

In 110-day-old foetuses there was further maturation of the papillae and it showed, filiform, fungiform and vallate papillae, with the lamina propria showing full differentiation (Fig. 7). Scant evidence of keratinization was seen in the filiform papillae (Fig. 8). Muscle bundle, collagenous fibres, blood vessels and gustatory glands were well developed.

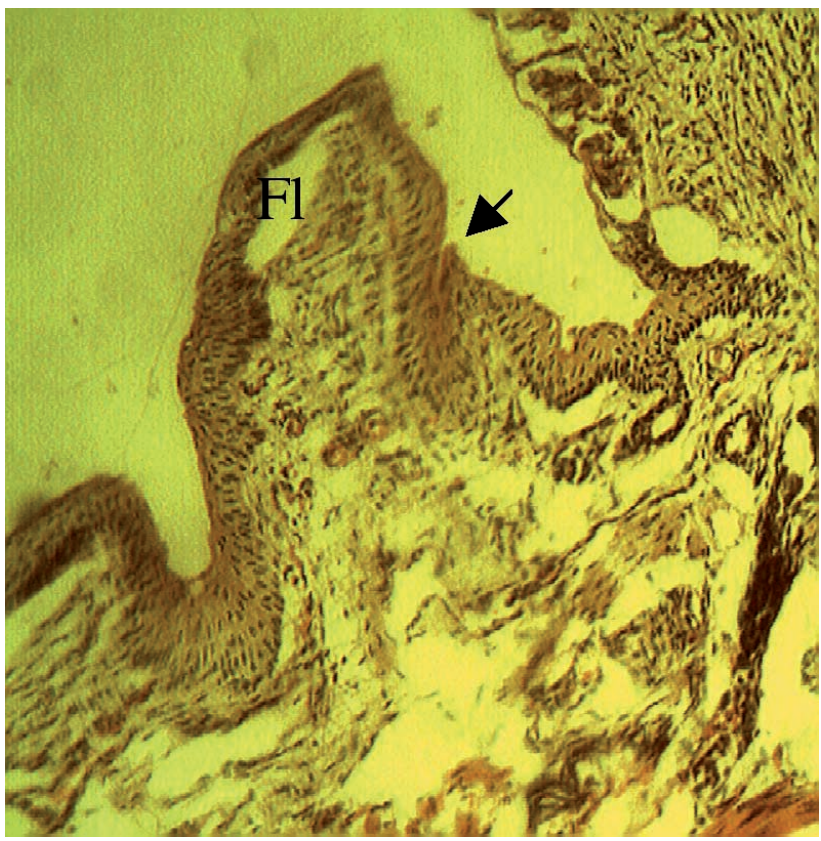

Fig. 8. 110-Day; Filiform papillae, scant keratinization (Arrow) H \& E. X200. 
In the prepubertal goats, the filiform in the lingual epithelium showed heavy keratinization. Muscle bundle, nerves were quite abundant in the lamina propria. Taste buds were apparent (Figs. 9 and 10). Other features observed in the previous age groups showed further marked maturation.

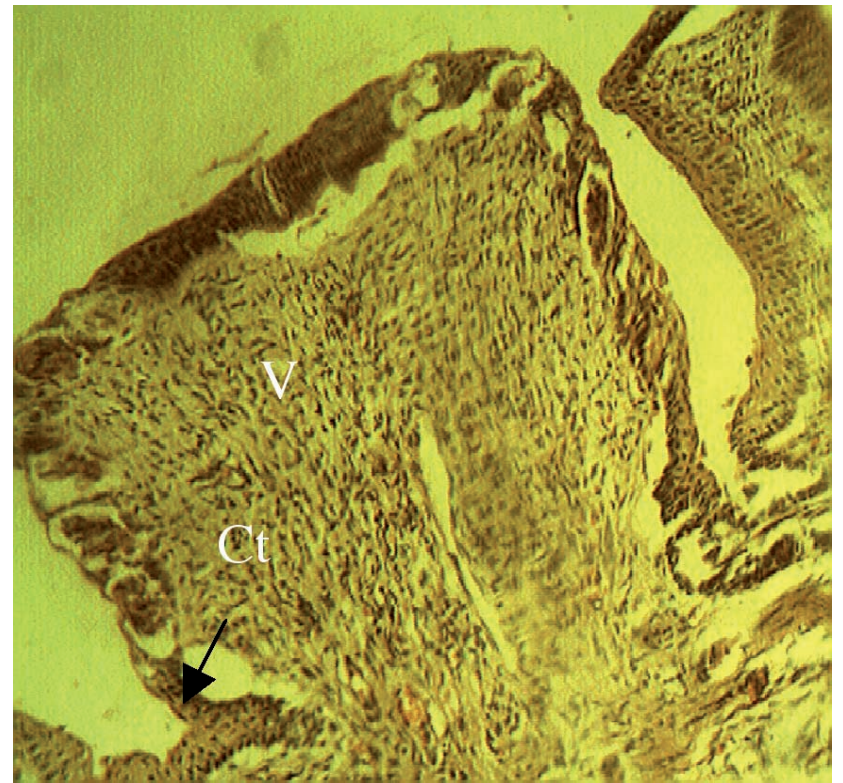

Fig. 9. Prepubertal goats; Vallate papillae(V), rudiments of taste buds(arrows), connective tissue core(Ct). H \& E. X400.

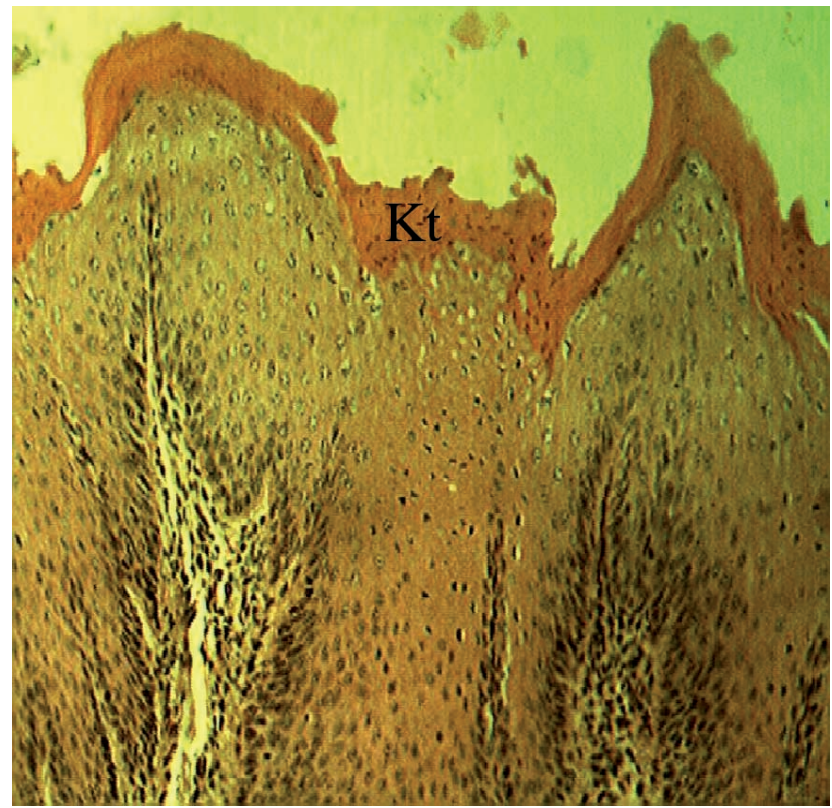

Fig. 10. Prepubertal goats; filiform papillae, keratin layer $(\mathrm{Kt}) \mathrm{H}$ \& E. X400.

\section{DISCUSSION}

The observations under light microcopy made it possible to following the developmental changes in the mucous membrane of the tongue from day 50 of prenatal life to prepubertal life in the Red Sokoto goat. The study focused on the development and morphology of primordial of some of the lingual papillae.

The observations were made in sections of specimen in median, transverse and dorsal planes. It was observed that at 50-day-old foetal life the epithelium covering the dorsum of the excamined apex, body and root the tongue have about 2-3 layers of the epithelium, showing thickening of the epithelium. Rudimentary evidence of future papillae formation was observed at this age. The mesenchymal tissue was located under the epithelium, which is found on a welldefined basement membrane. The lamina propria of the mucosa was scant.

The 65 to 90-day -old fetuses showed apparent primordial of different papillae, with additional thickening of the epithelium. The observed thickenings represent the first forms of primordial of fungiform and filiform papillae. Descriptions of the development of lingual papillae of mouse, rat and human has shown that early developmental stage of dome shaped structures found in the surface of the tongue were primordial of fungiform papillae (Iwasaki et al., 1996b, 1997; Witt \& Reutter).

Skeletal muscles fibers, blood vessels and some serious gustatory glands were well developed for 90-dayold foetuses. These observations are similar to the observations of Cho et al. (2005) in foetuses and neonates of Korean native goat (Capra hircus).

In this study the keratinization of the filiform and fungiform papillae apparently started about 90 day of foetal life. Other studies of Iwasaki et al. (1997) showed that the dorsal epithelium of the tongue in rats at the middle or late period of gestation has no rediments of filiform papillae and no sign of keratinization. In contrasts the rudiments of filiform papillae are clearlyrecognizable in the dorsal epithelium of the tongue of newborn rats just before birth; this morphogenesis of the filiform papillae of rats seems to occur rapidly during only 2 or 3 day, just before birth in parallel with keratinization of epithelium. By contrast the dorsal epithelium of human tongue becomes keratinized in the middle gestation (Sawarf et al., 1991). This may be due to different in duration of gestation which is longer in human, it appears that different factors affect the morphogenesis of rudiments of lingual papillae.

Thus agents such as growth factors and hormones (Iwasaki et al., 1997) should be examined for the role in different stages before and after birth to clarify the 
mechanism of morphogenesis of lingual papillae and differentiation of cells with different degrees of keratinization. The tongue is found in all vertebrates except fishes and some amphibians and the undulation as of the dorsal lingual surface are recognizable as a common feature of the tongues of most animals from amphibian to mammals (Iwasaki \& Kamakura, 1994; Iwasaki et al., 1996a, 1996b, 1997). Among reptiles (Iwasaki \& Kamakura) the keratinization of lingual epithelium is to adapt to dry land from fresh-water environment.

In the dorsum of the tongue of the prepubertral (Red Sokoto goat) is lined by keratinized stratified squamous epithelium. The superficial cells had polygonal shape with distinct bodies and mnicroridges. Similar features were reported in Horse (Chamorro et al., 1986), lesser mouse deer (Watanabe et al., 1995). According to Kubota (1968), there is an intimate relationship between the feeding habits and the development of the vallate papillae. Our finding showed that the connective tissue of vallate papillae present a central groove surrounded by connective tissue papillae with different height.

In conclusion, there are significant complex changes during the development of the mucous membrane of the tongue and its piapilla during the period from day 50 to day 110 of prenatal period, which is continued in the postnatal life.

IGBOKWE, C. O. \& OKOLIE, C. Observaciones morfológicas de algunas papilas linguales en las etapas prenatal y prepuberal de cabras rojas de Sokoto (Capra hircus). Int. J. Morphol., 27(1):145-150, 2009.

RESUMEN: El objetivo de este estudio fue investigar el desarrollo morfológico de la lengua en las etapas fetal y prepuberal de la cabra roja de Sokoto por microscopía de luz. En los fetos de alrededor de 50 días, los tejidos linguales mostraron un engrosamiento del epitelio en cerca de 2-3 capas de células. En los fetos de alrededor de 65 días, se observó tejido mesenquimático bajo el epitelio. Rudimentos de algunas papilas se observaron en esta etapa. Fibras colágenas y vasos sanguíneos fueron observados de manera escasa en la lámina propria. En los 80 días de edad fetal, se observó la mayor diferenciación del epitelio con algunos rudimentos de papilas, lo que continuó hasta la maduración de los fetos, alrededor de los 90 y 110 días, donde fueron observados de manera temprana rudimentos de botones gustativos. Evidencia de queratinización fue evidente en las etapas prepuberales.

PALABRAS CLAVE: Desarrollo; Papila lingual; Cabras rojas de Sokoto.

\section{REFERENCES}

Ahpin, I.; Ellis, S.; Arnott, C. \& Kaufman, M. H. Prenatal development and innervations of the circumvallate papillae in the mouse. J. Anat., 162:33-42, 1989.

Bloom, W. \& Fawcett, D. A Textbook of Histology. $12^{\text {th }}$. ed. Philadelphia, Saunders Company, 1994.

Chamorro, C. A.; Sanoval, J. \& Fernandez, J. G. Comparative scanning electron microscopic study of the gustatory papillae in two species oof domesctic animal (Equi caballus, Bos taurus). Acta Anat., 125:83-7, 1986.

Cho, C. H.; Kim, C. S.; Koh, P. O.; Kang, B. I.; Lee, J. H. \& Won, C. K. Morphological study on the development of the tongue in fetuses and neonates of Korean native goat (Capra hircus). Korean J.Vet. Sci., 45(4):477-84, 2005.

Dellman, H. Textbook of Veterinary Histology. Philadelphia, Lea and Febiger, 2006. pp.477-83.

Fujimoto, S.; Yamamoto, K.; Yoshizuka, M. \& Yokoyama, M. Pre and post-natal development of rabbit foliate papillae with reference to foliate gutter formation and taste bud differentiation. Microsc. Res. Tech., 26:12032, 1993.

Ham, A. W. \& Cormack, D. H. Textbook of Histology. $8^{\text {th }}$ ed. Philadelphia and Toronto, Lippincott, 1979. pp.647-50.

Iwasaki, S. \& Kumakura, M. An ultrastructural study of the dorsal lingual epithelium of rat snake (Elaphe guadrivigata). Ann. Anat., 176:455-62, 1994.

Iwasaki, S.; Wanichanon, C. \& Asami, T. Histological and ultrastructural study of the lingual epithelium of juvenile pacific turtle. Acta Anat., 178:143-250,1996a.

Iwasaki, S.; Yoshizawa, H. \& Kawahara, I. Study by scanning electron microscopyof the morphogenesis of three papillae in the mouse. Acta Anat., 157:41-52, 1996b.

Iwasaki, S.; Yoshizawa, H. \& Kawahara, N. Study by electron microscopy of three lingual papillae in the rat. Anat. Rec., 247:528-41, 1997. 
Kubota, K. Comparative anatomy and neurophysiological observations on the tongue of Northern fur seal. Anat. Rec., 161:257-66, 1968.

Kuwalik, M. The development of the mucous membrane of the tongue with emphasis on the development of fungiform papillae in the prenatal life of the rabbit. Electron. J. Pol. Agric.Univ. Ser.Vet. Med., 8:4, 2005 a.

Kuwalik, M. Morphology of the mucous membrane of the tongue with special emphasis on the papillae in the period from day one to 6 months of postnatal life in the rabbit. Acta Sci. Pol. Med. Vet., 4(2):47-58, 2005 b.

Richardson, C. M.; Heubet, C. N. \& Terlecki, C. Estimation of developmental age of ovine foetus and lamb. Vet. Rev., 99:22-4, 1976.

Sawarf, M. H.; Shabana, A. H. \& Qutayoun, J. P. Characterization of cytokeratin patterns in the developing human tongue. Inter. J. Dev. Biol., 35:91-100, 1991.

Soan, S.; Bertoni, G.; Gunudi, G. \& Botti, P. Anatomical radiographical study of prenatal development of bovine fetal teeth. Anat. Histol. Embryol., 26:107-13, 1997.

Tichy, F. The morphogenesis of selected lingual papillae in ovine and porcine fetuses observed by light microscopy. Acta Vet. Brno., 61:3-10, 1992.

Watanabe, L.; Beaga, L. \& Tedesco, R. C. Scanning electron microscopic study of the dorsal surface of the tongue of mouse. Ann. Anat., 177:569-72, 1995.

Witt, M. \& Reutter, K. Scanning electron microscopic studies of developing gustatory papillae in humans. Chem. Senses, 22:601-12, 1997.
Correspondence to:

Igbokwe, C. O.

Email:papacas@yahoo.com

Received: 11-03-2008

Accepted: 12-11-2008 